\title{
Penggunaan Kortikosteroid pada Pasien Anak dengan Perikarditis Tuberkulosis
}

\author{
Novi Violona Edwar ${ }^{1}$, Abi Andayu ${ }^{1}$, Finny Fitry Yani ${ }^{1}$ \\ ${ }^{1}$ Bagian IImu Kesehatan Anak, Fakultas Kedokteran Universitas Andalas
}

A B S T R A C T

\begin{abstract}
Perikarditis tuberkulosis ( Pericarditis TB ) merupakan penyakit yang masih sering terjadi di negara berkembang, Angka kematian akibat perikarditis TB masih cukup tinggi yaitu mencapai $17-40 \%$. Kematian aklibat perikarditis tuberkulosis dipengaruhi oleh adekuat atau tidaknya pengobatan. Penggunaan terapi tambahan kortikosteroid masih menjadi perdebatan dalam pengobatan perikarditis tuberkulosis. Penulisan kasus ini bertujuan untuk melihat keluaran dari penggunaan kortikosteroid pada pasien dengan perikarditis tuberkulosis. Penelusuran literatur dilakukan melalui Pubmed dan Google Scholar. Dari hasil penelusuran literatur didapatkan dua meta analisis pada yang membahas penggunaan kortikosteroid pada perikarditis tuberkulosis. Pada anak dengan perikarditis tuberkulosis, penggunaan kortikosteroid tidak menurunkan angka kematian, tetapi dapat mengurangi komplikasi akibat perikarditis tuberkulosis.

Kata kunci : keluaran, kortikosteroid, perikarditis tuberkulosis,
\end{abstract}

\section{Apa yang sudah diketahui tentang topik ini?}

Perikarditis tuberkulosis menjadi penyebab kematian akibat TB yang cukup tinggi mencapai $17-40 \%$. Penggunaan terapi tambahan kortikosteroid masih menjadi perdebatan
Tuberculous pericarditis (TB pericarditis) is a disease that still frequently occurs in developing countries. The mortality rate due to TB pericarditis is still quite high, reaching $17-40 \%$. Death due to tuberculous pericarditis is influenced by adequate or not treatment. The use of additional corticosteroid therapy is still a matter of debate in the treatment of tuberculous pericarditis. Writing this case aims to see the outcome of the use of corticosteroids in patients with tuberculous pericarditis. Literature searches were carried out through Pubmed and Google Scholar. From the results of literature search, two meta-analyzes were obtained that discussed the use of corticosteroids in tuberculous pericarditis. In children with tuberculous pericarditis, the use of corticosteroids does not reduce mortality, but can reduce complications due to tuberculous pericarditis.

Keywords: corticosteroids, tuberculous pericarditis, outcome.

\section{Apa yang ditambahkan pada studi ini?}

Luaran penggunaan kortikosteroid pada pasien anak

dengan pericarditis tuberkulosis

\section{CORRESPONDING AUTHOR}

Phone: +62 821-2188-0053

E-mail: finnyfy@yahoo.com

\section{ARTICLE INFORMATION}

Received: May $3^{r d}, 2021$

Revised: May $19^{\text {th }}, 2021$

Available online: May $27^{\text {th }}, 2021$

\section{Pendahuluan}

Perikarditis tuberkulosis ( Pericarditis TB ) merupakan penyakit Tuberkulosis (TB) ekstra paru yang jarang terjadi di negara maju, namun angka kejadian penyakit ini masih tinggi di negara berkenbang, terutama pada pasien dengan immunocompromise. Tuberkulosis (TB) adalah salah satu penyebab kematian anak yang utama, terutama di daerah endemis. ${ }^{1}$ Angka kematian akibat perikarditis TB mencapai $17-40 \%$ dan dipengaruhi oleh adekuat atau tidaknya pengobatan. Tanpa pengobatan yang memadai, harapan hidup rata-rata adalah 3,7 bulan, dengan hanya $20 \%$ yang bertahan sampai bulan keenam. ${ }^{2}$ 
Penggunaan kortikosteroid dapat menurunkan kesakitan dan kematian akibat perikarditis tuberkulosis, tetapi pengunaanya masih belum direkomendasikan secara umum kepada setiap pasien perikarditis tuberkulosis. ${ }^{3}$

\section{Kasus}

Seorang anak perempuan usia 16 tahun 6 bulan, dirawat di bangsal Anak RSUP Dr. M Djamil Padang dari tanggal 1 Juli 2020 sampai dengan 16 Juli 2020. Anak datang dengan keluhan sakit perut semakin berat sejak 3 hari yang lalu. Sakit perut berulang sudah dirasakan sejak 3 bulan yang lalu, sakit hilang timbul, dirasakan terutama di ulu hati. Saat sakit muncul dada terasa menyesak, sakit meningkat jika pasien menarik napas dalam dan berbaring, berkurang jika posisi setengah duduk. Anak tampak pucat sejak 1 bulan yang lalu. Demam hilang timbul sejak 1 minggu yang lalu. Mual ada, muntah ada sejak 1 minggu yang lalu, Sesak napas sejak 4 hari yang lalu, sesak terutama saat batuk, riwayat batuk berdahak tidak ada. Nafsu makan menurun dan kaki tampak bengkak sejak 4 hari yang lalu. Riwayat penurunan berat badan selama sakit disangkal, pasien tidak pernah ditimbang sebelumnya. Ayah pasien menderita $\mathrm{TB}$, telah menjalani pengobatan selama 9 bulan dan telah dinyatakan sembuh.

Pada pemeriksaan fisik, didapatkan rhonki basah halus di basal paru, peningkatan JVP, ictus cordis tidak terlihat, bunyi jantung yang melemah. Sedangkan pada pemeriksaan radiologi toraks didapatkan gambaran kardiomegali dengan bendungan paru. Pada gambaran echocardiography ditemukan efusi masif pada perikardium. Terapi yang diberikan kepada pasien ini yaitu berupa 02 nasal 2 LPM, IVFD Kaen 1B 65 cc/jam (restriksi 20\%), furosemid 1 x $40 \mathrm{mg}$, prednison $3 \times \quad x \quad 3$ tab $(1 \mathrm{mg} / \mathrm{KgBB} / \mathrm{hari})$, paracetamol $3 \times 500 \mathrm{mg}$.

\section{Rumusan Masalah}

Berdasarkan pendahuluan dan kasus di atas, maka dibentuklah rumusan masalah yaitu : bagaimana luaran penggunaan kortikosteroid pada pasien dengan perikarditis tuberkulosis.

\section{Metode/Penelusuran Bukti}

Pencarian artikel dilakukan melalui database Pubmed dan Google Scholar dengan menggunakan kata kunci sesuai dengan PICO dari pertanyaan https://doi.org/10.25077/ jikesi.v1i3.484 klinis yaitu: P (Problem) : Pasien dengan perikarditis tuberkulosis, I ( Intervention ) : pemberian kortikosteroid, C (Comparison) : tidak diberikan kortikosteroid dan $\mathrm{O}$ (Outcome) : tingkat kesembuhan dan kematian.

Kata kunci yang digunakan pada pencarian artikel yaitu: Tuberculous pericarditis AND Corticosteroid AND Outcome".

Kriteria inklusi pada pencarian artikel adalah artikel yang diterbitkan dalam 20 Tahun terakhir, berbahasa indonesia atau inggris. Jenis desain penelitian dibatasi dalam bentuk kohort, studi prospektif , studi retrospektif, systematic review dan meta analisis. Tidak ada kriteria eksklusi pada telaah jurnal ini.

\section{Hasil Penelusuran Bukti}

Dari hasil penelusuran artikel melalui Pubmed dengan menggunakan kata kunci yang telah ditetapkan didapatkan 30 hasil artikel dan melalui Google Scholar sebanyak 16.800 artikel. Penelaah kemudian melakukan telaah abstrak untuk memilih artikel yang sesuai dengan rumusan masalah.

Dari hasil penelusuran abstrak, penelaah mendapatkan dua meta analisis yang memenuhi kriteria eligibilitas, dilakukan telaah kritis dengan menggunakan Critical Appraisal Tool untuk studi meta analisis dari The Centre for Evidence -based Medicine (EBCM). Kedua meta analisis tersebut membahas tentang luaran penggunaan kortikosteroid pada pasien dengan tuberkulosis.

Tabel 1. Studi Luaran Penggunaan Kortikosteroid pada Pasien dengan Tuberkulosis

\begin{tabular}{|c|c|c|c|c|}
\hline Artikel & $\begin{array}{l}\text { Desain } \\
\text { Studi }\end{array}$ & Populasi & Intervensi & Outcome \\
\hline $\begin{array}{l}\text { A. } \\
\text { George, } \\
\text { B. } \\
\text { Thomas, } \\
\text { J. S. S. } \\
\text { Sadhu. }{ }^{4}\end{array}$ & $\begin{array}{l}\text { Meta } \\
\text { analisis }\end{array}$ & $\begin{array}{l}\text { Pasien } \\
\text { usia 5-18 } \\
\text { tahun } \\
\text { dengan } \\
\text { perikardi } \\
\text { tis } \\
\text { tuberkul } \\
\text { osis }\end{array}$ & $\begin{array}{l}\text { Pemberian } \\
\text { prednisolon } \\
5-120 \mathrm{mg} / \\
\text { hari selama } \\
6 \quad-11 \\
\text { minggu }\end{array}$ & $\begin{array}{l}\text { Tidak } \\
\text { menurunk } \\
\text { an angka } \\
\text { kematian }\end{array}$ \\
\hline $\begin{array}{l}\text { Julia A } \\
\text { Critchley } \\
\text { ' Fiona } \\
\text { Young, } \\
\text { Lois } \\
\text { Orton, } \\
\text { Paul } \\
\text { Garner } 5\end{array}$ & $\begin{array}{l}\text { Meta } \\
\text { analisis }\end{array}$ & $\begin{array}{l}\text { Pasien } \\
\text { dengan } \\
\text { tuberkul } \\
\text { osis }\end{array}$ & $\begin{array}{l}\text { Pemberian } \\
\text { prednisolon } \\
\text { e } 4-60 \mathrm{mg} \\
\text { selama } 30 \\
\text { hari - } 15 \\
\text { minggu }\end{array}$ & $\begin{array}{l}\text { Menurunk } \\
\text { an angka } \\
\text { kematian } \\
\text { pada } \\
\text { semua } \\
\text { jenis } \\
\text { tuberkulo } \\
\text { sis }\end{array}$ \\
\hline
\end{tabular}




\section{Diskusi}

Perikarditis tuberkulosis (TB) merupakan infeksi pada perikardium yang disebabkan oleh Mycobacterium Tubercullosis (MTB). Infeksi pada perikardium ini dapat menimbulkan akumulasi cairan pada rongga pembungkus jantung. ${ }^{6}$ Efusi perikardium tuberkulosis merupakan salah satu manifestasi TB ekstraparu yang sering terjadi. ${ }^{7}$ Manifestasi klinis perikarditis TB adalah sesak napas, peningkatan tekanan vena jugularis, apeks jantung tidak teraba atau bunyi jantung melemah, dan nyeri dada. ${ }^{7}$

Mekanisme terjadinya manifestasi klinis perikarditis adalah akumulasi cairan di dalam perikardium yang menekan ventrikel jantung dan menghambat pengisian serta kontraksi jantung (tamponade) atau penebalan perikardium dengan efusi minimal yang mengakibatkan gangguan pengisian jantung pada fase diastol. ${ }^{8}$

Pada pasien ini ditemukan gejala sesak nafas, peningkatan tekanan vena jugularis $(5+4 \mathrm{~cm})$, ictus cordis tidak terlihat, serta bunyi jantung yang melemah, gejala - gejala ini sesuai dengan gejala dan tanda pada perikarditis tuberkulosis.

Tatalaksana perikarditis TB meliputi pemberian obat anti tuberkulosis (OAT), kortikosteroid, perikardiosintesis dan perikardiektomi. Tujuan pembunuhan dan pengendalian Mtb yang efektif dengan menggunakan empat regimen obat anti tuberkulosis (rifampisin, isoniazid, etambutol, dan pirazinamid) selama minimal 6 bulan telah menjadi standar perawatan selama beberapa dekade. ${ }^{8}$

OAT berperan besar dalam menurunkan angka kematian pada pasien perikarditis TB, menurut World Health Organization (WHO) pemberian OAT pada perikarditis TB sama sengan pemberian OAT lainnya yaitu kategori I, menurut Perhimpunan Dokter Paru Indonesia (PDPI) pemberian OAT pada perikarditis TB selama 9-12 bulan dengan penambahan steroid. ${ }^{9}$

Pasien ini mendapatkan terapi kortikosteroid berupa prednison 3 x 3 tab (dosis 1 $\mathrm{mg} / \mathrm{kgBB} /$ hari) pada hari pertama perawatan. Pasien mendapat terapi FDC 1 × 3 tablet pada hari perawatan ke 6 setelah hasil pemeriksaan gene xpert menunjukkan hasil sputum positif, sensitif rifampisin.

Manfaat pemakaian kortikosteroid dalam tatalaksana perikarditis TB masih diperdebatkan.
Beberapa peneliti berpendapat bahwa kortikosteroid bermanfaat, karena dapat menekan respons inflamasi dini dan mempercepat penyerapan kembali cairan perikardium, sehingga terjadinya komplikasi perikardium konstriksi dapat dicegah.6 Pemberian kortikosteroid diindikasikan pada kasus efusi persisten atau kambuh selama 3 bulan.10 Dosis prednison adalah 1-2 mg/kgbb/ hari selama 5-7 hari dan dikurangi bertahap selama 6-8 minggu. ${ }^{9}$

Pasien mendapatkan terapi OAT yaitu FDC $1 \mathrm{x}$ 3 tablet selama 6 bulan dan terapi prednison dengan dosis $1 \mathrm{mg} / \mathrm{kgBB} /$ hari. Kondisi pasien tidak ada keluhan dan sudah beraktifitas seperti biasanya dengan tidak ditemukan adanya pembesaran jantun dan infiltrat pada paru.

Metaanalisis yang ditemukan pada telaah ini mendapatkan hasil bahwa penggunaan kortikosteroid tidak menurunkan angka kematian akibat perikarditis tuberkulosis, tetapi dapat menurunkan komplikasi yang terjadi seperti perikarditis konstriktif. Tetapi meta analisis ini memiliki keterbatasan dalam jumlah RCT (Randomized Controll Trial) yang digunakan dan setting yang dilakukan beberapa penelitianya dilakukan sebelum era infeksi HIV (Human Immnodeficiency Virus). ${ }^{4}$

\section{Kesimpulan}

Dari hasil penelaahan artikel, penelaah menarik kesimpulan penggunaan kortikosteroid pada pasien anak dengan perikarditis tuberkulosis tidak menurunkan angka kematian tetapi dapat menurunkan komplikasi akibat perikarditis tuberkulosis. Sehingga pada pasien ini, tetap diperlukan penggunaan kortikosteroid dalam tatalaksana perikarditis tuberkulosis. Hasil kesimpulan ini sesuai dengan hasil yang didapatkan pada gambaran kasus, dimana luaran yang dihasilkan dari pemberian kortikosteroid dan OAT memberikan hasil luaran yang baik.

\section{Daftar Pustaka}

1. Adler $\mathrm{Y}$, Charron P, Imazio M, Badano L, BarónEsquivias G, Bogaert J, et al. 2015 ESC Guidelines for the diagnosis and management of pericardial diseases. Eur Heart J. 2015;36(42):2921-64.

2. Paramitha W, Murni IK, Arguni E, Setyowireni D. Tuberculosis pericarditis in Adolescents: A case series. Paediatr Indones. 2020;60(2):111-6.

3. Ntsekhe M, Wiysonge C, Volmink JA, Commerford PJ. Adjuvant corticosteroids for tuberculous pericarditis : promising , but not proven. 2003;5939. 
4. George IA, Thomas B, Sadhu JS. Systematic review and meta-analysis of adjunctive corticosteroids in the treatment of tuberculous pericarditis. Int J Tuberc Lung Dis. 2018;22(5):551-6.

5. Critchley JA, Young F, Orton L, Garner P. Corticosteroids for prevention of mortality in people with tuberculosis: A systematic review and metaanalysis. Lancet Infect Dis [Internet]. 2013;13(3):223-37. Available from: http://dx.doi.org/10.1016/S1473-3099(12)70321-3

6. Syafina I. Pericarditis tuberkulosis. Anat Med J. 2019;2(3):135-46.

7. Obihara NJ, Walters E, Lawrenson J, Garcia-Prats AJ, Hesseling AC, Schaaf HS. Tuberculous pericardial effusions in children. J Pediatric Infect Dis Soc. 2018;7(4):346-9.

8. Isiguzo G, Du Bruyn E, Howlett $P$, Ntsekhe $M$. Diagnosis and management of tuberculous pericarditis: What is new? Curr Cardiol Rep. 2020;22(1).

9. World Health Organization. WHO consolidated guidelines on tuberculosis: Rapid diagnostics for Tuberculosis detection. Switzerland; 2020 p. 1-61.

10. Shenje J, Lai RP, Ross IL, Mayosi BM, Wilkinson RJ, Ntsekhe $M$, et al. Effect of prednisolone on inflammatory markers in pericardial tuberculosis : A pilot study. IJC Hear Vasc. 2018;18:104-8. 